\title{
Every Three Years
}

National Cancer Institute

\section{Source}

National Cancer Institute. Every Three Years. NCI Thesaurus. Code C161333.

Planned or occurring every three years. 